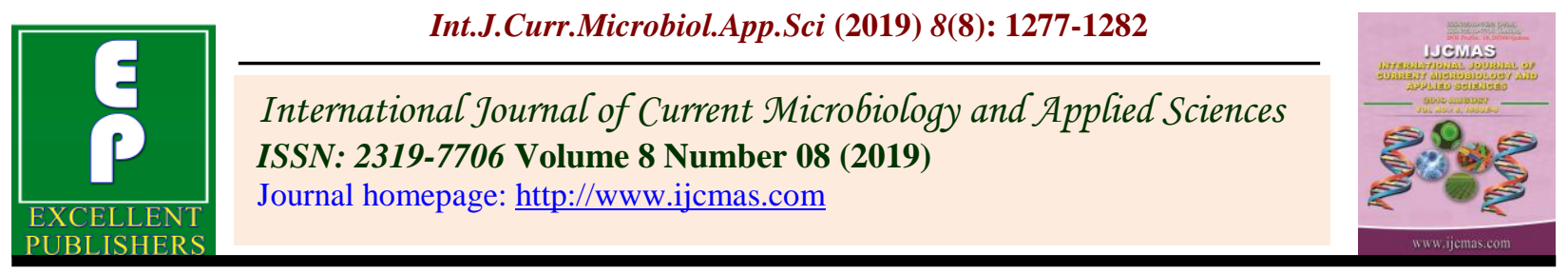

Original Research Article https://doi.org/10.20546/ijcmas.2019.808.150

\title{
Response of Okra (Abelmoschus esculentus L.) to Foliar Application of Silicon
}

\author{
J.M. Vashi*, B.M. Tandel, S.N. Saravaiya, A.I. Patel and B.N. Chaudhari \\ Department of Vegetable Science, ASPEE College of Horticulture and Forestry, Navsari \\ Agricultural University, Navsari 396 450, Gujarat, India \\ *Corresponding author
}

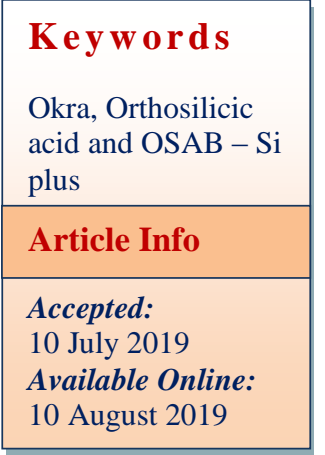

\section{A B S T R A C T}

A field experiment was carried out, with a view to study the Response of okra (Abelmoschus esculentus L.) to foliar application of silicon at Vegetable Research Scheme, Regional Horticultural Research Station of the Navsari Agricultural University, Navsari, Gujarat, India between 2015 to 2017 during summer season. The experiment was conducted in Randomized Block Design with three repetitions. Foliar application of Orthosilicic acid and Oligomeric silicic acid + Boric acid (OSAB - Si plus) was given at 30, 45 and 60 DAS at 0.02, 0.04 and 0.06 percentage level. The results revealed that higher values for growth and yield characters namely, plant height, chlorophyll content, number of fruits per plant and fruit yield (kg/ha) were recorded higher Oligomeric silicic acid + Boric acid (OSAB - Si plus) at 0.02 percentage level during all the three years of experiment.

\section{Introduction}

Okra [Abelmoschus esculentus (L.) Moench] popularly known as lady's finger, is believed to be a native of Ethiopia. It is herbaceous annual plant belongs to family Malvacae growing in warm season as well as rainy season of both tropical and subtropical regions of the world. Okra is extensively grown in India throughout the year for its tender nonfibrous edible fruit. It is very popular among the farmers because of easy in growing and has wider adaptability range. It has good nutritional value. Besides being a vegetable, it also has medicinal and industrial important. India is the largest producer of okra. It is mainly used for its tender green fruits as vegetable in many countries (Bayer and Kubitzki, 2003). Okra has a prominent position among vegetable fruits due to its high nutritive and medicinal value, ease of cultivation and wider adaptability to varying weathers (Reddy et al., 2012).

Silicon ( $\mathrm{Si}$ ) constitutes $27.8 \%(\mathrm{w} / \mathrm{w})$ in earth's crust which occurs as silica $\left(\mathrm{SiO}_{2}\right)$ and 
silicates $\left(\mathrm{SiO}_{3}\right)$ but not in its elemental form (Ehrlich, 1981). Silicon content in soil ranges from < 1 to $45 \%$ by dry weight (Sommer et al., 2006) while the silica ( $\mathrm{Si}$ to $\mathrm{SiO}_{2}-2.1$; $\mathrm{Si}$ to $\left.\mathrm{SiO}_{3}-2.6\right)$ constitute $50-70 \%$ of the soil mass varying from less than $20 \%$ to almost $100 \%$. All plants rooting in soil therefore contain silicon.

Yet it is considered as a plant nutrient "anomaly" as its essentiality for plants is not yet established (Epstein, 1994). But soluble silicon was found to enhance plant growth and yield of many crop plants, protect them from pests and diseases and hence accepted as an agronomically beneficial element (Epstein, 1999). The quantity of silicon removed from the world arable soils is estimated as 210-224 million tons annually (FAO, 1998). The usefulness of silicon in different spheres of human life was well elucidated (Vasanthi et al., 2012). Objective of this research was to investigate the effect of foliar applicaton of silicon on overall performance of okra during the summer season.

\section{Materials and Methods}

The experiment was undertaken at the Vegetable Research Scheme, Regional Horticultural Research Station of the Navsari Agricultural University, Navsari, Gujarat, India during summer season of 2015 to 2017. The experiment was conducted in Randomized block design with three repetition. Details of the treatments are., $\mathrm{T}_{1}$ Orthosilicic acid $0.02 \%$ ( At 30,45 \& 60 DAS), $\mathrm{T}_{2}$ - Orthosilicic acid $0.04 \%$ (At 30,45 \& 60 DAS), $\mathrm{T}_{3}$ - Orthosilicic acid $0.06 \%$ (At $30,45 \& 60$ DAS), $\mathrm{T}_{4}$ - Oligomeric silicic acid and Boric acid (OSAB- Si Plus) $0.02 \%$ (At 30,45 \& 60 DAS), T5-Oligomeric silicic acid and Boric acid (OSAB- Si Plus) $0.04 \%$ (At 30,45 \& 60 DAS), $\mathrm{T}_{6}$-Oligomeric silicic acid and Boric acid (OSAB- Si Plus) $0.06 \%$ (At $30,45 \quad \& \quad 60$ DAS) and $\mathrm{T}_{7^{-}}$Control.
Furthermore during all three growing season sowing of okra was completed during second fortnight of February. All the recommended cultural practises and manure and fertilizer was given regularly.

For recording different field observations, five plants of okra from each net plot area were selected randomly in the beginning and tagged with the labels. Plant height was measured with help of meter tape at final harvest, number of fruits per plant of taaged plant count individually and yield $(\mathrm{kg} / \mathrm{ha})$ were worked out with the yield from net plot area.

\section{Results and Discussion}

The data presented in table 1 revealed that the application of OSAB- Si Plus (Oligomeric silicic acid and Boric acid at $0.02 \%$ ) at 30, 45 and 60 DAS recorded maximum plant height $(88.79 \mathrm{~cm}, 87.26 \mathrm{~cm}$, and $79.57 \mathrm{~cm})$. Decreased in occurrence of diseases with foliar application of silicon fertilizer resulting in increased the plant height and growth of okra plants (Liu, 1997). Similar results in potato with application of silicon were reported by Luz et al., (2008). In tomato silicon fertilizer application induced higher growth reported by Gowda et al., (2015).

In case of chlorophyll content of okra same treatment OSAB - Si plus(Oligomeric silicic acid and Boric acid at $0.02 \%$ ) recorded higher chlorophyll content during all the three year of experiments $(1.47,1.38$ and $1.20 \mathrm{mg} / 100 \mathrm{~g}$, respectively). Similar results were observed by Liu (1997) with the application of silicon fertilizers increased the chlorophyll content in leaves of tomato plants. Similar results in tomato were also reported by Emrich et al., (2011).

Treatment containing Oligomeric silicic acid and Boric acid at $0.02 \%$ at 30, 45 and 60 DAS recorded better growth (Table 1). 
Table.1 Effect of Silicon on growth characters of okra

\begin{tabular}{|c|c|c|c|c|c|c|c|c|}
\hline \multirow[t]{2}{*}{ Treatments } & \multicolumn{4}{|c|}{ Plant height (cm) } & \multicolumn{4}{|c|}{ Chlorophyll content $\mathrm{mg} / \mathbf{1 0 0 g}$} \\
\hline & 2015 & 2016 & 2017 & POOLED & 2015 & 2016 & 2017 & POOLED \\
\hline $\mathbf{T}_{1}$ & 82.93 & 81.32 & 71.45 & 78.57 & 1.15 & 1.03 & 0.68 & 0.95 \\
\hline $\mathbf{T}_{2}$ & 81.59 & 78.94 & 71.95 & 77.49 & 1.03 & 0.84 & 0.63 & 0.83 \\
\hline $\mathbf{T}_{\mathbf{3}}$ & 79.82 & 79.76 & 73.46 & 77.68 & 0.99 & 0.95 & 0.74 & 0.89 \\
\hline $\mathbf{T}_{4}$ & 88.79 & 87.26 & 79.57 & 85.21 & 1.47 & 1.38 & 1.20 & 1.35 \\
\hline $\mathbf{T}_{5}$ & 80.11 & 80.01 & 70.21 & 76.77 & 1.34 & 1.25 & 1.01 & 1.20 \\
\hline $\mathbf{T}_{6}$ & 77.64 & 75.78 & 71.42 & 74.95 & 1.02 & 0.80 & 0.69 & 0.84 \\
\hline $\mathbf{T}_{7}$ & 64.88 & 64.68 & 67.86 & 65.80 & 0.70 & 0.67 & 0.57 & 0.65 \\
\hline S. Em \pm & 4.47 & 4.22 & 3.57 & 2.30 & 0.03 & 0.06 & 0.04 & 0.03 \\
\hline CD at $5 \%$ & 13.28 & 12.54 & NS & 6.50 & 0.09 & 0.18 & 0.12 & 0.08 \\
\hline CV\% & 11.26 & 10.79 & 9.87 & 10.38 & 5.35 & 12.26 & 10.21 & 9.72 \\
\hline
\end{tabular}

Table.2 Effect of Silicon on yield characters of okra

\begin{tabular}{|c|c|c|c|c|c|c|c|c|c|c|c|c|}
\hline & \multicolumn{4}{|c|}{ Fruit per plant of okra } & \multicolumn{4}{|c|}{ Fruit weight (g) } & \multicolumn{3}{c|}{ Yield (kg/ha) } \\
\hline Treatments & $\mathbf{2 0 1 5}$ & $\mathbf{2 0 1 6}$ & $\mathbf{2 0 1 7}$ & POOLED & $\mathbf{2 0 1 5}$ & $\mathbf{2 0 1 6}$ & $\mathbf{2 0 1 7}$ & POOLED & $\mathbf{2 0 1 5}$ & $\mathbf{2 0 1 6}$ & $\mathbf{2 0 1 7}$ & POOLED \\
\hline $\mathbf{T}_{\mathbf{1}}$ & 15.87 & 13.79 & 9.21 & 12.96 & 161.68 & 135.13 & 105.39 & 134.07 & 11996.28 & 10009.62 & 7911.92 & 9972.61 \\
\hline $\mathbf{T}_{\mathbf{2}}$ & 14.77 & 13.59 & 9.23 & 12.53 & 148.13 & 128.54 & 100.81 & 125.83 & 11370.83 & 9521.29 & 7553.30 & 9481.81 \\
\hline $\mathbf{T}_{\mathbf{3}}$ & 13.07 & 13.34 & 11.09 & 12.50 & 132.13 & 131.50 & 116.52 & 126.72 & 9632.28 & 9740.36 & 8524.30 & 9298.98 \\
\hline $\mathbf{T}_{\mathbf{4}}$ & 19.92 & 17.24 & 15.19 & 17.45 & 201.81 & 177.50 & 161.58 & 180.30 & 14968.50 & 13148.32 & 11996.73 & 13371.18 \\
\hline $\mathbf{T}_{\mathbf{5}}$ & 17.42 & 16.08 & 12.30 & 15.27 & 176.58 & 171.00 & 132.08 & 159.89 & 13099.99 & 12666.47 & 9941.97 & 11902.81 \\
\hline $\mathbf{T}_{\mathbf{6}}$ & 13.77 & 13.34 & 10.39 & 12.50 & 140.83 & 120.51 & 114.47 & 125.27 & 10451.84 & 8926.66 & 8410.54 & 9263.01 \\
\hline $\mathbf{T}_{\mathbf{7}}$ & 11.17 & 11.08 & 9.05 & 10.44 & 113.71 & 106.81 & 99.23 & 106.58 & 8192.34 & 7912.03 & 7239.30 & 7781.22 \\
\hline S. Em $\mathbf{E}$ & $\mathbf{0 . 8 4}$ & $\mathbf{0 . 6 9}$ & $\mathbf{0 . 5 4}$ & $\mathbf{0 . 4 0}$ & $\mathbf{8 . 3 1}$ & $\mathbf{6 . 4 0}$ & $\mathbf{5 . 9 0}$ & $\mathbf{3 . 9 0}$ & $\mathbf{6 1 8 . 0 4}$ & $\mathbf{4 7 4 . 1 8}$ & $\mathbf{4 7 8 . 9 2}$ & $\mathbf{2 9 5 . 6 3}$ \\
\hline CD at 5\% & $\mathbf{2 . 5 0}$ & $\mathbf{2 . 0 6}$ & $\mathbf{1 . 6 0}$ & $\mathbf{1 . 1 3}$ & $\mathbf{2 4 . 6 8}$ & $\mathbf{1 9 . 0 2}$ & $\mathbf{1 7 . 5 2}$ & $\mathbf{1 1 . 0 4}$ & $\mathbf{1 8 3 6 . 3 0}$ & $\mathbf{1 4 0 8 . 8 7}$ & $\mathbf{1 4 2 2 . 9 4}$ & $\mathbf{8 3 6 . 3 0}$ \\
\hline CV \% & $\mathbf{1 1 . 1 2}$ & $\mathbf{9 . 8 6}$ & $\mathbf{9 . 8 8}$ & $\mathbf{1 0 . 3 9}$ & $\mathbf{1 0 . 8 2}$ & $\mathbf{9 . 2 3}$ & $\mathbf{9 . 9 4}$ & $\mathbf{9 . 8 8}$ & $\mathbf{1 0 . 8 5}$ & $\mathbf{9 . 2 3}$ & $\mathbf{1 0 . 8 9}$ & $\mathbf{1 0 . 0 9}$ \\
\hline
\end{tabular}


The increase in growth parameter due to the stimulation of growth by silicon could be either indirect, owing to the protective effects of silicon against pathogens or direct as it impacts both morphological changes and physiological processes in plants. It seems that it is involved directly or indirectly in cell metabolism (Liang et al., 1993). Adatia and Besford (1986) and Seung et al., (2005) reported the increased plant height with the application of silica as salicylic acid in cucumber. Similar findings were also reported by Elawad et al., (1982), Savant et al., (1999) and Yoshida (1975) in zinnia.

Yield parameters (Table 2) viz., number of fruits per plant (19.92,17.24 and 15.19), fruit weight $(201.81 \mathrm{~g}, 177.50 \mathrm{~g}$ and $161.58 \mathrm{~g})$ as well as yield $\mathrm{kg} / \mathrm{ha}(14968.50,13148.32$ and 11996.73) during all the three respective years (2015,2016 and 2017) were found maximum in treatment $\mathrm{T}_{4}$ (Oligomeric silicic acid and Boric acid at $0.02 \%$ ) at 30, 45 and 60 DAS.

Silicon is still not consider as essential element, positive effect has been reported in case of increase in yield, enhanced pollination and most commonly increased disease resistance has been very well presented in melons (Gilman et al., 2003).Similarly, Tesfagioris et al., (2008) reported that increased plant yield with the application silicon base chemicals results in maximum growth in Zucchini and Zinnia by decreasing the disease incidence. Aziz et al., (2001) reported that increased pollen fertility in melon plants with the application of silica resulting in more yield.

Furthermore promotional effect of the foliar application of silicon on growth and yield characters of okra found in this research, may be related to the direct effect of silicon on plant resistance to both biotic and abiotic stress including drought (Glenn et al., 2002 and Creamer et al., 2005). Slicon was also reported to alleviate water stress by its reduction effect on the diameter of stomatal pores (Efimova and Dokynchan, 1986) which in turns, reduces transpiration rate resulting in reduction in water loss. Another possible effect of silicon in the improvement in the efficiency of osmotic adjustment of plant tissues (Romero-Aranda and Cuartero, 2006). Silicon playes key role in retaining the water capacity of stressed cells, which thereby can tolerate severe drought (Crusciol et al., 2009). Silicon was reported to enhance rigidity, strengthening and elasticity of cell wall also it promotes plant growth by correcting the cytokinnins under stress conditions (Hanafy et al., 2008).

The study investigated the response of okra to foliar application of silicon on growth and yield characters of okra. Among the all treatments, $\mathrm{T}_{4}$ - Oligomeric silicic acid and Boric acid (OSAB - Si Plus) $0.02 \%$ (At 30, $45 \& 60$ DAS) were found best.

\section{References}

Adatia, M. H. and R. T. Besford (1986). The effect of silicon in cucumber plants grown in re-circulating nutrient solution. Annals of Botany, 58: 43-351.

Aziz, T. M., M. S. Akhtar and I. Ahmed (2001). Differential growth response of cotton genotypes infected with root rot to silicon nutrition. Pakistan J. of Soil Sci., 20: 101-108.

Bayer, C. and Kubitzki, K. (2003). Malvaceae. p. 225-311. In: The Families and Genera of Vascular Plants, Vol. V. Flowering Plants Dicotyledons, K. Kubitzki (ed.). Springer, Berlin Heidelberg.

Creamer, R.; S. Sanogo and O. A. El-Sebai (2005). Kaolin-based foliar reflectant affects physiology and incidence of beet curly top virus but not yield of Chile pepper. Hort sci., 40(3): 574-576. 
Crucicol, C.A.C.; A.L. Pulz; L.B. Lemos; R.P. Soratto and G.P.P. Lima (2009). Effects of silicon and drought stress on tuber yield and leaf biochemical characteristics in potato. Crop Physiology and Metabolism, 49:949954.

Efimova, G. V. and S. A. Dokynchan (1986). Anatomo-morphological construction of epidermal tissue of rice leaves and increasing of its protection function under silicon effect. Agric. Biol., 3:5761.

Ehrlich, H.L. (1981). Geomicrobiology. Marcel Dekker Inc., Newyork.pp. 393.

Elawad, S. H., J. J. Street and G. J. Gascho. (1982). Response of sugarcane to silicate source and rate of growth and yield.

Emrich, E. B., R. J. Souza, A. A. De Lima, F. C. De Figueiredo and D. R. G. Silva (2011). Cultivation of tomato in organic substrates under leaf spraying of potassium silicate in protected environment. Ciencia e Agrotecnologia, 35(1): 56-61.

Epstein, E. (1994). The anomaly of silicon in plant biology. Proc.Natl.Acad.Sci. USA, 91: 11-17.

Epstein, E. (1999). Silicon. Annu.Rev. Pl.Physiol. Mol.Biol., 50: 641-664.

FAO. (1998). World Agricultural Center, FAOSTAT agricultural statistic data base gateway.

Gilman, J. H., D. C. Zlesak and J. A. Smith (2003). Application of potassium silicate decrease black spot infection in Rosa hybrida. Hort sci., 38: 44-1147.

Glenn, D. M., E. Prado, A. Erez, J. McFerson and G. J. Puterka (2002). A reflective, processed-kaolin particle film affects fruit temperature, radiation reflection, and solar injury in apple. J. Amer. Soc. Hort. Sci., 127: 188-193.

Gowda, D.C.; Lingaiah, H.B.; Nachegowda, V. and Anil kumar, S. (2015). Effect of speciality fertilizers on growth and yield of tomato (Solanum lycopersicon L.). Plant Archives, 15 (01): 335-338.

Hanafy, A. H.; E. M. Harb, M. A. Higazy and S. H. Morgan (2008). Effect of silicon and boron foliar applications on wheat plants grown under saline soil conditions. Int.J. Agric. Res., 3(1): 1-26.

Liang, Y. C., X. M. Chen, T. S. Ma and L. R. Liu. (1993). Effect of silicon on growth, yield and quality of tomato. Agri.Sci., 4: 48-50.

Liu, H. Y. (1997). Preliminary report on effect of silicon fertilizers on tomato growth. J. of guaizhou Agri., 16: 76-77.

Luz, J. M., C. R. Rodrigues, M. V. Goncalves and L. Coelho (2008). The effect of silicate on potatoes in minas gerais, Brazil. IV Silicon in Agriculture Conference. pp. 48.

Reddy, M. T., Haribabu, K., Ganesh, M., Reddy, K. C. and Begum, H. (2012). Genetic divergence analysis of indigenous and exotic collections of okra [Abelmoschus esculentus (L.) Moench]. J. Agric. Tech. 28: 611-23.

Romero-Aranda, M. R. and O. J. J. Cuartero (2006). Silicon alleviates the deleterious salt effect on tomato plant growth by improving plant water status. J. Plant Physi., 163: 847-855.

Savant, N. K., G. H. Korndorfer, L. E. Datnoff and Gii (1999). Silicon nutrition and sugarcane production. $J$. of Plant Nutri., 22: 1853-1903.

Seung, J., P. HanMin and R. Byoung (2005). Effect of potassium silicate on the growth of miniature rose 'pinocchio' grown on rockwool and its cut flower quality. J.of Japan Soc. of Hort. Sci., 74(3): 242-247.

Sommer, M.D., Fuzyakov and Breuer J. (2006). Silicon pools and fluxes in soils and landscapes-a review. J.Plant Nutr. Soil Sci., 169: 310-329.

Tesfagiorgis, H. B., M. D. Laing and M. J. 
Morris (2008). Uptake and distribution of silicon on zucchini and zinnia and its interaction with other elements. IV Silicon in Agriculture Conference. pp 101.

Vasanthi, N., Saleena L.M. and Anthoni Raj
S. (2012). Silicon in day today life. World J. Appl. Sci., 17: 1425-1440.

Yoshida, S. (1975). Effects of silica and nitrogen supply on some characters of the rice plant. Plant and Soil, 31: 4856.

\section{How to cite this article:}

Vashi, J.M., B.M. Tandel, S.N. Saravaiya, A.I. Patel and Chaudhari, B.N. 2019. Response of Okra (Abelmoschus esculentus L.) to Foliar Application of Silicon. Int.J.Curr.Microbiol.App.Sci. 8(08): 1277-1282. doi: https://doi.org/10.20546/ijcmas.2019.808.150 